\title{
Characterization and typology of sheep and goat production systems in the State of Paraíba, a semi-arid region of northeastern Brazil
}

\section{Caracterização dos sistemas de produção de ovinos e caprinos no Estado da Paraíba, Semiárido do Nordeste, Brasil}

\author{
Ricardo de Figueiredo Guilherme ${ }^{1}$; Ana Milena César Lima²; \\ José Romero Alexandre Alves ${ }^{1}$; Diego Figueiredo da Costa ${ }^{1}$; \\ Raymundo Rizaldo Pinheiro ${ }^{3}$; Francisco Selmo Fernandes Alves ${ }^{3}$; \\ Sérgio Santos de Azevedo ${ }^{4}$; Clebert José Alves ${ }^{4 *}$
}

\begin{abstract}
Breeding of goats and sheep is an important activity in northeast Brazil, contributing to economic and social development of this region. Thus, the objective of this study was to characterize goat and sheep rearing and breeding in the central-western region of the State of Paraíba, northeast Brazil. The study area included Borborema and mesoregions of the backlands of the state, represented by 127 municipalities in an area of $38.293 \mathrm{~km}^{2}$, with density of goats and sheep at 12.9 and $8.27 \mathrm{head} / \mathrm{km}^{2}$, respectively. A total of 62 farms belonging to five municipalities of the Borborema mesoregion and four municipalities of the Sertão mesoregion were surveyed. Epidemiological surveys were conducted in the farms, and questionnaires sought information on the economic, productive, and social aspects of the farm owners and the farms. The results allowed the classification of goat and sheep production systems in the semi-arid Paraíba as a family system and of subsistence, for farmers' own consumption and for local trade, with low technology use and herds with up to 100 animals. The farmers' level of education was low, and the investments and technical assistance for the development of breeding activity in the region were insufficient and/or inadequate. Thus, it was essential to conduct an economic study on the farms to assess the actual economic and financial status of breeding activity and the subsequent returns. It is suggested that these aspects be taken into account when planning livestock development policies, especially in terms of finance and technical assistance, as well as in the implementation of strategies to control commonly occurring diseases in the region, aimed at combating agents, environmental control, and protection of susceptible livestock.
\end{abstract}

Key words: Goats. Sheep. Production Systems. Productive Characteristics.

\section{Resumo}

A criação de caprinos e ovinos é uma atividade de grande importância para o Nordeste, contribuindo para o desenvolvimento econômico e social da região. Diante disso, objetivou-se caracterizar a

\footnotetext{
${ }^{1}$ Discentes, Curso de Doutorado, Programa de Pós-Graduação em Medicina Veterinária, Universidade Federal de Campina Grande, UFCG, Patos, PB, Brasil. E-mail: ricardo.figueiredo@hotmail.com; j.romeroalves@bol.com.br; diegoveter@hotmail. com

${ }^{2}$ Bolsista de Aperfeiçoamento, Centro de pesquisa de Caprinos e Ovinos, CNPC, Empresa Brasileira de Pesquisa Agropecuária, EMBRAPA Caprinos e Ovinos, Sobral, CE, Brasil. E-mail: anamilenalima@yahoo.com.br

${ }^{3}$ Pesquisadores, Centro de Pesquisa de Caprinos e Ovinos, CNPC, EMBRAPA Caprinos e Ovinos, Sobral, CE, Brasil. E-mail: selmo.alves@embrapa.br; rizaldo.pinheiro@embrapa.br

${ }^{4}$ Profs., Programa de Pós-Graduação em Medicina Veterinária, UFCG, Patos, PB, Brasil. E-mail: sergio@vps.fmvz.usp.br; clebertja@uol.com.br

* Author for correspondence
} 
caprinovinocultura na região Centro-Oeste do Estado da Paraíba, Nordeste do Brasil. A pesquisa abrangeu as mesorregiões da Borborema e Sertão do Estado, representadas por 127 municípios e uma área de $38.293 \mathrm{~km}^{2}$, que apresentam uma densidade de caprinos e ovinos de 12,9 e 8,27 cabeças/ $\mathrm{km}^{2}$, respectivamente. No total foram visitadas 62 propriedades pertencentes a cinco municípios da Mesorregião da Borborema e quatro da Mesorregião do Sertão. Nas propriedades foram aplicados questionários epidemiológicos, os quais buscavam informações sobre aspectos econômicos, produtivos e sociais dos proprietários/propriedades. Os resultados obtidos permitem classificar o sistema de produção de caprinos e ovinos no semiárido paraibano como familiar e de subsistência, para consumo doméstico e comércio local, com baixo uso de tecnologia e rebanhos com até 100 animais. O nível de escolaridade dos criadores foi considerado baixo, bem como os investimentos e assistência técnica insuficientes e/ou inadequados para o desenvolvimento da atividade na região. Dessa forma, um estudo econômico nas propriedades para conhecimento da real situação econômico-financeira da atividade e o retorno que as mesmas poderão proporcionar a partir da sua organização se torna necessário. Sugere-se que tais aspectos sejam levados em consideração quanto ao planejamento de políticas de desenvolvimento pecuário, especialmente quando relacionados a financiamento e assistência técnica, bem como na implementação de ações no controle das doenças mais frequentes na região, direcionadas ao combate aos agentes, controle ambiental e proteção dos susceptíveis.

Palavras-chave: Caprinos. Ovinos. Sistemas de Produção.Características produtivas.

\section{Introduction}

The state of Paraíba is located in the northeastern region of Brazil and a large part of its territory is in the semi-arid region (GIRARDI; ROSA, 2011). With a population of approximately 473,184 goats and 374,081 sheep, goat and sheep rearing stands out as an extremely important activity for income generation and, above all, the subsistence of small families of farmers in the region (PUGH; BAIRD, 2012).

Currently, goats and sheep are found in most municipalities in Paraíba, some with a fewer number of animals and others with large numbers, such as Sumé and Monteiro, which have the largest goat herds in the state (IBGE, 2014). Despite the large number of animals, technical and sanitary deficiencies, and lack of characterization of production systems limit the development of this activity, especially due to the lack of socio-economic and production profile analyses of agricultural and livestock production systems (SOUZA et al., 2009).

The lack of information about this agribusiness, as well as the lack of data on the number and location of productive farms has hindered the implementation of preventive, socio-economic, and marketing measures in sheep and goat rearing.
There is also a consequent lack of knowledge about the actual number of farmers and the livestock's conditions and characteristics. Therefore, the study of the rural areas in various mesoregions in the state of Paraíba is an important in order to contribute to the orientation of development programs for used by institutions responsible for the formulation of public policies, as well as in planning and implementing rural extension services in this region. Thus, the objective of this study was to characterize the production systems of sheep and goats in the semiarid region of the state of Paraíba.

\section{Material and Methods}

The research was carried out in the centralwestern region of the state of Paraíba, specifically in the Borborema and Sertão mesoregions, which are represented by 127 municipalities in an area of $38.293 \mathrm{~km}^{2}$, with a density of goats and sheep at 12.9 and $8.27 \mathrm{head} / \mathrm{km}^{2}$, respectively (IBGE, 2012). The nine municipalities selected for the research represent approximately $40 \%$ of the goat and sheep herds of Paraíba (Figure 1). The state of Paraíba is subdivided into three climatic regions: humid tropical Atlantic coast, Borborema Plateau, and Sertão. Although the region of Sertão presents 
higher rainfall indices compared to Borborema, the two climatic regions are located within the semiarid region and have Caatinga as the predominant natural vegetation (ALVES, 2009). Caatinga (from Tupi-Guarani: caa [vegetation] + tinga [white] = white vegetation), is the only exclusive Brazilian biome and occupies almost $11 \%$ of its national territory. It is characterized by being adapted to arid conditions (xerophilous), with the presence of shrubs with twisted branches and deep roots and also cactuses and bromeliads. The shrubs lose almost all their leaves during droughts (COSTA et al., 2011).

Figure 1. Geographic representation of the cities surveyed in the State of Paraíba.

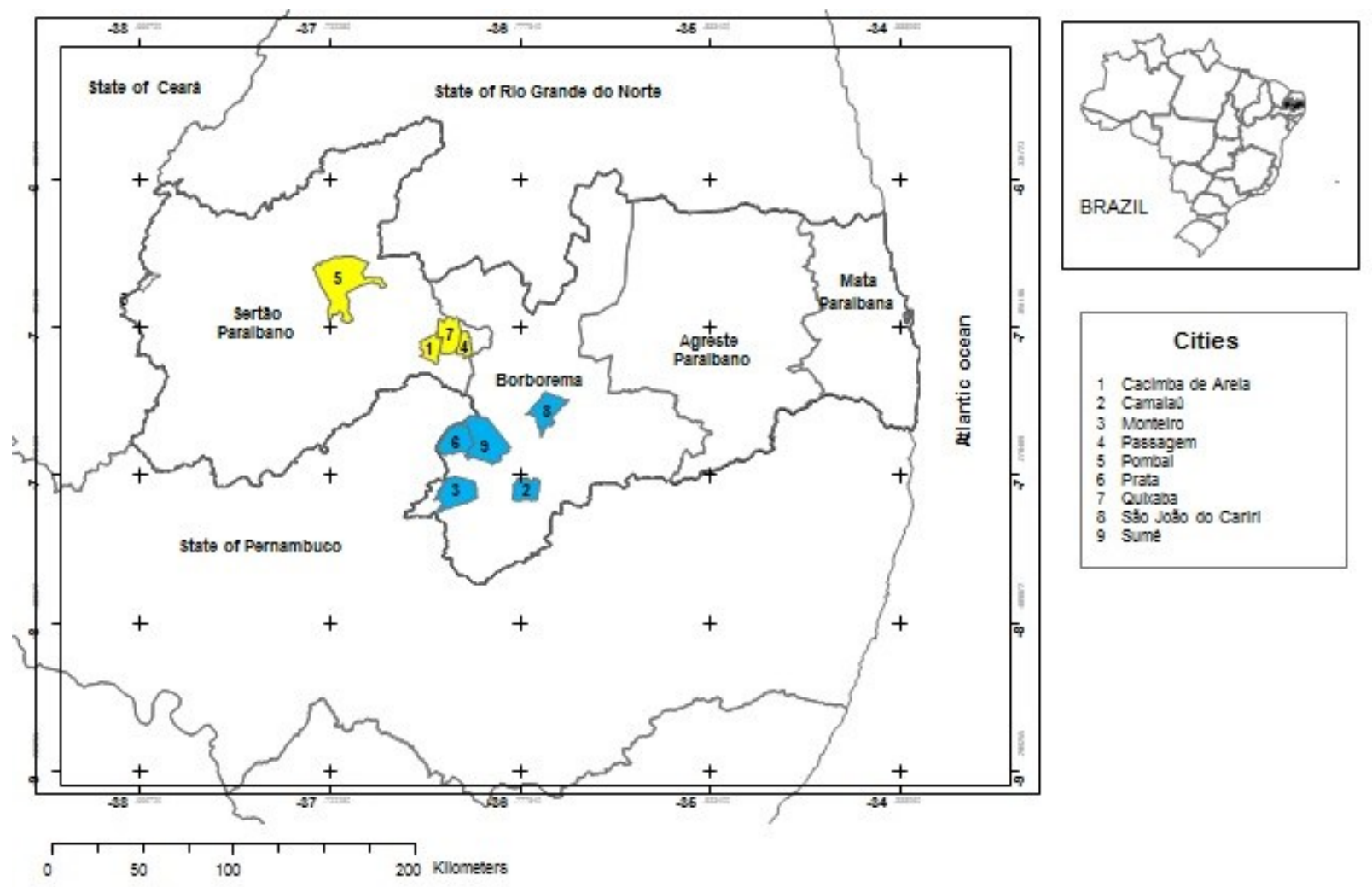

In this study, 62 farms were surveyed in the municipalities of Monteiro (18), Prata (5), Camalaú (5), Sumé (9), and São João do Cariri (4) in the mesoregion of Borborema, and Quixaba (5), Cacimba de Areia (4), Pombal (2), and Passagem (10) in the mesoregion of Sertão. Information was collected by using questionnaires comprising qualitative and quantitative information, subdivided into sections. In each farm, selected by convenience, this questionnaire was applied, and the adopted criterion for the inclusion of a farm was the rearing of goats and/or sheep. Of the 62 farmers interviewed,
60 were men and two were women. The criteria for defining social, economic, and technical issues were EMBRAPA's own database, which was based on studies carried out by a specialized team in the area. The sections were identified as infrastructure, herd, social variables, and technical variables, with the purpose of obtaining information related to the characterization of the farm, the profile of the producer, and the technological level.

A structured interview type was used; the questions were formulated with the purpose of obtaining appropriate answers to fulfill the research 
objective, according to the methodology described by Santos (2014) and Lima (2015). The producers were interviewed at their farms by technicians and university scholarship holders of EMBRAPA, with in loco supervision of EMBRAPA researchers. The questions, response options, and questioning sequence were identical for all interviewed farmers in order to ensure that variations between responses were due to individual differences rather than the interviewers, thus seeking to identify and evaluate the main management systems adopted.

The data collected from the questionnaire were organized into a database in Microsoft Excel ${ }^{\circledR}$ spreadsheets. Following this, simple frequency analysis was performed using STATISTICA Trial software (2009).

\section{Results and Discussion}

Regarding the level of education, a high level of education is important for the success of technical training; $\geq 83.9 \%$ of the producers had an education level of elementary school I (i.e., the first five years of elementary school in Brazil) (Table 1). However, because of the limited quality of public education in the interior regions of the country, especially in "rural cities," it would be prudent to consider that only high school farmers can respond successfully to technical training programs.

Table 1. Social profile analysis of sheep and goat producers in the semi-arid region of Paraíba.

\begin{tabular}{|c|c|c|}
\hline Variables & $\mathrm{N}$ & $\%$ \\
\hline \multicolumn{3}{|l|}{ Level of education } \\
\hline Illiterate & 10 & 16.1 \\
\hline Elementary school I & 10 & 16.1 \\
\hline Elementary school II & 25 & 40.4 \\
\hline High school & 17 & 27.4 \\
\hline \multicolumn{3}{|c|}{ Producer training in the activity } \\
\hline Yes & 19 & 30.6 \\
\hline No & 43 & 69.4 \\
\hline \multicolumn{3}{|l|}{ Place of residence } \\
\hline In town & 27 & 27.4 \\
\hline In the farm & 45 & 72.6 \\
\hline \multicolumn{3}{|l|}{ Financing } \\
\hline Yes & 38 & 61.3 \\
\hline No & 24 & 38.7 \\
\hline \multicolumn{3}{|l|}{ Accounting } \\
\hline Annual & 22 & 36.3 \\
\hline Eventual & 16 & 25.0 \\
\hline Does not make & 24 & 38.7 \\
\hline \multicolumn{3}{|c|}{ Participation in trade unions } \\
\hline Yes & 39 & 63.0 \\
\hline No & 23 & 37.0 \\
\hline \multicolumn{3}{|c|}{ Development of other activities } \\
\hline Yes & 40 & 65.0 \\
\hline No & 22 & 35.0 \\
\hline \multicolumn{3}{|l|}{ Type of activity } \\
\hline Trade & 10 & 25.0 \\
\hline Student & 02 & 5.0 \\
\hline Agriculture & 25 & 64.0 \\
\hline Others & 03 & 6.0 \\
\hline
\end{tabular}

$\mathrm{N}=$ number of answers in the questionnaire

$\%=$ percentage of answers in the questionnaire. 
The results of this study indicate an improvement in the education level scenario compared to the study conducted by SEBRAE-PB (2004) in the city of São João do Cariri-PB, which indicated a high percentage of producers between the levels of illiteracy and elementary school I. Costa et al. (2011) conducted a study in the city of Monteiro-PB; they indicated that these results would consequently reflect on the production profile, management techniques, and sanitary practices adopted, also considering that the educational level can be directly related to the existing technological level in the farm, because people with a higher level of education have greater ease in understanding and assimilating new technologies, and consequently there is an increased probability of these new technologies being adopted by them (MONTE; TEIXEIRA, 2006).

Approximately $72.6 \%$ of the producers lived on the farms, while $27.4 \%$ lived in the cities and regularly visited the farm (Table 1). These results are consistent with the results of Silva et al. (2013) in the municipalities of Cariri, Paraíba, where $68.7 \%$ of the producers lived on the farm, while $31.3 \%$ lived in the urban area and visited their herds daily. The place of residence of the producer is relevant, since it contributes to increasing the time dedicated to the activity, thereby facilitating identification and solution of problems, consequently resulting in a better administration (HOLANDA JUNIOR; CAMPOS, 2003).

Most of the producers made investments through bank financing for raising sheep and goats. However, it seems that the production systems of goat and sheep failed to advance in accordance with the investments made, since these production systems are characterized by low production rates, inadequate management practices, poor sanitation, low investment capacity, and low technological absorption (PINHEIRO et al., 2000; RIETCORREA et al., 2013).

It was observed that agriculture was the main occupation of a large proportion of farmers (64\%). Since agriculture is generally associated with livestock, it indicates that the profile of farmers' families also includes livestock breeding. With regard to those who performed other activities besides livestock rearing and breeding, trading is another major occupation (25\%). Usually, people who follow market trends also engage in some commercial activity. In this case, the proportion of traders confirms the growth projection of the goat and sheep market, since most of them who fit into this profile have commercial activity as secondary activity.

The farmers were asked about the frequency of performing accounting of their activity; 38.7\% did not perform it, $36.3 \%$ performed it annually although without financial deepening, and only $25 \%$ of the interviewed farmers performed it eventually by recording expenditure and revenue (Table 1). The fact that the producers do not perform or only perform their accounting eventually reveals the lack of financial planning, considering that this balance is essential for the advancement of any economic activity.

This study showed that approximately $63 \%$ of the producers participated in unions $(63 \%)$, which was the main form of organization. This indicates that rural unions exist in the lives of the interviewed farmers. Although this system of cooperation serves as an alternative for the development of the producers, encouraging them to act in associative organizations and participate in public policies (BRITO, 2006), it is observed that unions are more focused on the social security of the union members than on the development of production activity.

The average age of the producers interviewed in the nine municipalities was 52.2 years (Table 2). According to Lima and Baiardi (2000), this is a consequence of migration of young people to urban centers in search of better living conditions. On the other hand, the age of the producer can influence the administration of the farm, when comparing the differences in the expectations between young and old people. Young people are bold and innovative (HOLANDA JUNIOR; CAMPOS, 2003); however, the experience gained with age is also valuable (ALENCAR, 2008). 
Table 2. Quantitative variable analysis of the age of the producer, duration of the activity, and the labor used in goat and sheep rearing in the semi-arid region of Paraíba.

\begin{tabular}{lcc}
\hline Variables & Average & Standard deviation \\
\hline Producer age (years) & 52.2 & 13.8 \\
Duration of livestock activity (years) & 24.3 & 12.2 \\
Duration of sheep rearing (years) & 18.0 & 4.4 \\
Duration of goat rearing (years) & 18.0 & 4.4 \\
Family labor (men/day) & 3.0 & 1.3 \\
Hired labor (men/day) & 1.3 & 0.5 \\
\hline
\end{tabular}

Most of the producers have already been in the business for an average of 24.2 years and have raised goats and/or sheep for up to 18 years (Table 2). According to Faria et al. (2004), the duration of the exercise of an activity reflects its tradition and its growth. It is evident that the activity in the municipalities in this study is traditional and that the producers have already consolidated the breeding of goats and sheep in the state of Paraíba. Notably, bank financing and incentives for breeding are available in the northeastern states of Brazil, because of the tradition of raising small ruminants.

With regard to family labor, it was verified that the average size of the labor force was 3.0 men, dedicated daily to herding dairy goats, and planting and supplying forage palm according to the size of the herd. Unpaid family labor facilitates the development of the business and contributes to the reduction of costs towards external labor. However, some productive farms hired specialized labor, with an average of $1.34 \mathrm{men} /$ day for the management of the herd; this labor is characterized as seasonal, especially during rainy periods, according to theherds of dairy goats. Regarding the evaluation of facilities in the studied municipalities, $66 \%$ of the interviewed producers considered that their facilities (corrals, sheepfolds, enclosures for goats), mostly made of wood and clay tile (54\%) and on beaten dirt floor $(85 \%)$ were equipped to manage the operations (Table 3). Regarding the facilities, fences were present in most of the farms, and 66\% of the farms were equipped to house the animals, with the number of paddocks ranging from 6 to 10 in $74 \%$ of the farms, especially those with cultivated pastures.

Regarding water availability in the productive farms, in $65 \%$ of the producers had water available at their facilities, with dams being the main source of water $(42 \%)$, with irregular availability during the year. These results are consistent with those observed by Alencar et al. (2010) in the northeastern semi-arid region in farms in the hinterlands of the state of Pernambuco, where dams and/or wells are the main source of water used for breeding and rearing goats and sheep. In the present study, we emphasize the need for applying technologies that enable water storage in the rainy season to meet the requirement of water for rearing goats and sheep during most part of the year, because prolonged periods of drought can affect their activity of producers. 
Table 3. Qualitative variable analysis of the technological aspects favorable for goat and sheep rearing in the semi-arid region of Paraíba.

\begin{tabular}{|c|c|c|}
\hline Variables & $\mathrm{N}$ & $\%$ \\
\hline \multicolumn{3}{|c|}{ Facilities with adequate technological level } \\
\hline Yes & 40 & 66.0 \\
\hline No & 22 & 34.0 \\
\hline \multicolumn{3}{|l|}{ Material used in the sheepfolds } \\
\hline Wood with ceramic tile & 34 & 54.0 \\
\hline Masonry with ceramic tile & 01 & 2.0 \\
\hline Wood with asbestos tile & 13 & 21.0 \\
\hline Masonry with asbestos tile & 04 & 6.0 \\
\hline Wood covered with straw & 02 & 4.0 \\
\hline Does not have & 08 & 13.0 \\
\hline \multicolumn{3}{|l|}{ Sheepfold type } \\
\hline Suspended & 09 & 15.0 \\
\hline Beaten dirt floor & 53 & 85.0 \\
\hline \multicolumn{3}{|l|}{ Conservation of fences } \\
\hline Good & 42 & 68.0 \\
\hline Regular & 14 & 22.0 \\
\hline $\mathrm{Bad}$ & 06 & 10.0 \\
\hline \multicolumn{3}{|l|}{ Number of paddocks in the farm } \\
\hline$<5$ & 10 & 16.0 \\
\hline From 6 to 10 & 46 & 74.0 \\
\hline From 11 to 15 & 03 & 5.0 \\
\hline From 16 to 20 & 03 & 5.0 \\
\hline \multicolumn{3}{|l|}{ Main water source of the farm } \\
\hline Artesian well & 09 & 14.0 \\
\hline Dam & 26 & 42.0 \\
\hline River & 03 & 6.0 \\
\hline Well + Dam & 15 & 24.0 \\
\hline Dam + river & 09 & 14.0 \\
\hline \multicolumn{3}{|c|}{ Distribution of water in the facilities } \\
\hline Yes & 45 & 72.0 \\
\hline No & 17 & 28.0 \\
\hline
\end{tabular}

$\mathrm{N}=$ number of answers in the questionnaire

$\%=$ percentage of answers in the questionnaire.

The management system adopted was in the following order: intensive $<$ extensive $<$ semiintensive (Table 4). The semi-intensive breeding system predominated in $78 \%$ of the farms: this result was consistent with that of Gonçalves et al. (2008) in Southeast Brazil; however, it differed from the findings of Almeida et al. (2006) in northeast Brazil, where the extensive system was dominant. Under normal conditions, it is known that the extensive system is predominant in low-tech breeding with limited resources, as is the case of goat and sheep breeding in the northeast. However, it is important to highlight that the region is experiencing prolonged drought periods in recent years; therefore, this factor may have been decisive in this change of scenery, since dietary supplementation is not just an option, but a requirement for the activity to be viable. With regard to animal feeding, there was great variation in the type of bulk foods and concentrate supplied, as described (Table 4). Approximately 32\% of the farmers use the feeding system comprising native grass + cultivated pasture + concentrate + 
forage palm. The native pasture is typical of the Caatinga, which is highly adapted to the conditions of the semiarid (xerophilous), with the presence of shrubs with twisted branches and deep roots and the presence of cactuses and bromeliads. The shrubs lose almost all their leaves during droughts (COSTA et al., 2011). Among the several native species, the ones that need to be highlighted are: the Maniçoba (Manihot pseudoglaziovii), Catingueira (Caesalpinia pyramidalis), Catingueira Rasteira (Caesalpinia microphylla), Favela (Cnidoscolus phyllacanthus), Canafístula (Senna spectabilis), Marizeiro (Geoffroea spinosa) Mororó (Bauhinia sp.), Sabiá (Mimosa caesalpiniifolia) and Juazeiro (Ziziphus joazeiro) among the species of trees; the Jurema preta (Mimosa tenuiflora), and mata pasto (Senna sp.) among the shrub and subshrub species, and the forage cactuses, Facheiro (Pilosocereus pachycladus) and mandacaru (Cereus jamacaru)
(DRUMOND et al., 2004). In cultivated pastures, the grasses that predominate are those from Africa, especially grasses most adapted to semiaridity: Gramão (Cynodon dactylon), Urochloa spp., buffelgrass, and, with greater restriction, the Andropogon spp. The forage mass produced by some grasses grown in the semi-arid region may be modest, mainly due to the low and variable rainfall. Some low-lying lands and areas downstream of dams, which can retain moisture in the soil longer in the dry season, are used for the cultivation of elephant grass (OLIVEIRA et al., 1988). The association of native pasture with cultivated pasture has been used by several producers based on the results of studies presented by EMBRAPA, such as the association of Caatinga with buffelgrass (Cenchrus ciliares) and Leucena (Leucaena leucocephala) (GUIMARÃES FILHO, 1994; GUIMARÃES FILHO; SOARES, 1999; BANDEIRA et al., 2007).

Table 4. Qualitative variable analysis of the technological aspects favorable for goat and sheep rearing in the semi-arid region of Paraíba.

\begin{tabular}{lcc}
\hline Variables & $\mathrm{N}$ & $\%$ \\
\hline Facilities with adequate technological level & & 14.0 \\
Extensive & 10 & 78.0 \\
Semi-intensive & 47 & 8.0 \\
Intensive & 05 & 6.0 \\
Feeding of animals & & 12.0 \\
NP + C & 04 & 8.0 \\
NP + FP & 07 & 32.0 \\
NP + FP + C & 05 & 14.0 \\
NP + CP + C + FP & 20 & 10.0 \\
CP + C & 09 & 8.0 \\
CP + FP & 06 & 10.0 \\
CP + FP + C & 05 & 24.0 \\
CP + NP + C & 06 & 76.0 \\
Adoption of forage conservation practices & & \\
Yes & 15 & 5.0 \\
No & 47 & 19.0 \\
What type of conservation is used & & 76.0 \\
Silage & 03 & \\
Hay & 12 & 86.0 \\
Does not do & 47 & 14.0 \\
Use of mineral supplement & & \\
Yes & 53 & 09 \\
No & 09 & \\
\hline
\end{tabular}

$\mathrm{NP}=$ native pasture, $\mathrm{CP}=$ cultivated pasture, $\mathrm{FP}=$ forage palm, $\mathrm{C}=$ concentrate $\mathrm{N}=$ number of answers $\%=$ percentage of answers. 
In the present study, $70 \%$ of the interviewed farmers used forage palm (Opuntia spp) as an alternative source of food reserve; however, because of pest attacks on the plantations by the cochineal (Diaspis echinocacti), production of this crop decreased remarkably in the farms. Forage palm mortality caused by this pest has also been described in other municipalities in the region (RIET-CORREA et al., 2013). Successful adaptation and resistance to the climatic conditions of the region make the forage palm an important food alternative, especially in the dry season, because it is a green food that has a high energy value for milk production and that supplies a great part of the animals' water needs; therefore, it is the most sustainable method for intensifying production (ALMEIDA, 2012).

Regarding mineralization, most producers adopted this procedure, constituting a percentage of $86 \%$. Given the importance of this practice for the vital functions of animals, ideally, all producers should practice it. However, it should be noted that some producers offer cattle mineral supplements, which is extremely dangerous when provided to sheep, because the toxicity caused by copper can cause their death. In addition, it is necessary to consider that mineralization does not always follow a satisfactory technical orientation, and there may be cases of lack of minerals. In order to elucidate this aspect, it would be necessary to establish a specific study with the analysis of the feeding system of the herds. According to the study by Castro et al. (2007), copper intoxication represents a major problem in the south of Brazil, northeast region, and states of Mato Grosso do Sul and São Paulo; an outbreak of copper intoxication occurred in the interior of São Paulo with the administration of pelleted feed prepared for dairy cattle, and all animals that showed symptoms of the disease (six out of 20 sheep) died.

It was observed that $76 \%$ of the producers do not adopt practices of forage conservation. Among the issues raised regarding the absence of forage conservation in hay or silage were the lack of knowledge of the techniques, costs of hired labor in several phases of production, and competition with the production of food for human consumption, which often discourages the producer from producing and storing large volumes; these findings are consistent with described by Riet-Correa et al. (2013).

Genetic composition of the sheep and goats was conducive to meat production. The national sheep was represented predominantly by animals with No Breed Standard Set (NBSS) (40\%) and $30 \%$ were Santa Inês sheep. Regarding goats, the genetic composition was based on animals with No Breed Standard Set (NBSS) (36\%) and dairy breeds (64\%) (Table 5). This lack of breeding standard may indicate the lack of technology in the farms and, consequently, of investments in the activity, since to own a herd of purebred animals would require more efforts and costs for the management of these animals.

It was observed that the dairy goat breeds stood out in the composition of the herds in the farms of the studied municipalities, corresponding to more than $64 \%$ of the interviewed farmers, which, according to Souza et al. (2011), is due to the large use of reproducing males and/or reproducing females of this breed, despite being more demanding with regard to nutritional and management aspects, are more productive compared to the other breeds raised in the region.

Most of the herds have a population of less than 100 females for reproduction, and a considerable proportion of herds with fewer than twenty females. Obviously, the reduced number of reproducing females does not generate an income that favors the rearing of the small ruminants as a main business. The number of male goats for reproduction in $72 \%$ of the farms was five or fewer, and $69 \%$ of the farms surveyed had five or fewer male sheep for reproduction. 
Table 5. Quantitative and qualitative variable analysis of herd composition and type of goat and sheep in the semi-arid region of Paraíba.

\begin{tabular}{|c|c|c|}
\hline Variables & $\mathrm{N}$ & $\%$ \\
\hline \multicolumn{3}{|l|}{ Genetic composition of the sheep } \\
\hline Santa Inês & 17 & 30.0 \\
\hline No Breed Standard Set (NBSS) & 26 & 40.0 \\
\hline Dorper & 03 & 5.0 \\
\hline $1 / 2$ Santa Inês $+1 / 2$ NBSS & 16 & 25.0 \\
\hline \multicolumn{3}{|l|}{ Genetic composition of the goats } \\
\hline Saanen and Saanen crossbreed & 15 & 24.0 \\
\hline Alpine and Alpine crossbreed & 05 & 8.0 \\
\hline Anglo Nubian and Anglo Nubian crossbreed & 20 & 32.0 \\
\hline No Breed Standard Set (NBSS) & 22 & 36.0 \\
\hline \multicolumn{3}{|l|}{ Total number of animals involved in the research } \\
\hline Number of sheep & 459 & 100.0 \\
\hline Number of goats & 1230 & 100.0 \\
\hline \multicolumn{3}{|l|}{ Distribution of animals by productive farm } \\
\hline Breed only goats & 38 & 60.0 \\
\hline Breed only sheep & 12 & 20.0 \\
\hline Breed goats and sheep & 12 & 20.0 \\
\hline \multicolumn{3}{|l|}{ Total number of female goats } \\
\hline$\leq 20$ & 06 & 10.0 \\
\hline From 21 to 100 & 53 & 85.0 \\
\hline$>100$ & 03 & 5.0 \\
\hline \multicolumn{3}{|l|}{ Total number of female sheep } \\
\hline$\leq 20$ & 11 & 18.0 \\
\hline From 21 to 100 & 43 & 70.0 \\
\hline$>100$ & 08 & 12.0 \\
\hline \multicolumn{3}{|l|}{ Total number of male goats for reproduction } \\
\hline Absence of male goats for reproduction & 06 & 8.0 \\
\hline From 1 to 5 & 44 & 72.0 \\
\hline$>5$ & 12 & 20.0 \\
\hline \multicolumn{3}{|l|}{ Total number of male sheep for reproduction } \\
\hline Absence of male sheep for reproduction & 03 & 5.0 \\
\hline From 1 to 5 & 43 & 69.0 \\
\hline$>5$ & 16 & 26.0 \\
\hline \multicolumn{3}{|l|}{ Type of herds } \\
\hline Milk & 30 & 49.0 \\
\hline Meat & 23 & 37.0 \\
\hline Mixed & 09 & 14.0 \\
\hline
\end{tabular}

$\mathrm{N}=$ number of answers in the questionnaire

$\%=$ percentage of answers in the questionnaire.

Regarding the ranch type, the predominance of dairy herds (49\%) was verified among the municipalities, especially for the goats. The intervention of the government through the "Milk Program of Paraíba" is very important, since guaranteeing the purchase of milk helps to revert social problems, such as the rural exodus, caused by the excess of population. Dairy goat breeding strongly motivates the permanence of families in the semi-arid region of Paraíba by generating an income, increasing the monetary circulation in the region, and reducing food insecurity through milk 
distribution in school meals and among needy families in the region.

Most producers (65\%) did not record productive, reproductive, or economic events. When this procedure was carried out $(35 \%)$, it recorded only mating, births, expenses, revenues, and parturition. In all other cases, controls were recorded mainly on cards (65\%) (Table 6). This study evidenced that farm management can help improve control of the productive activity.

Table 6. Qualitative variable analysis of the zootechnical aspects of goat and sheep rearing in the semi-arid region of Paraíba.

\begin{tabular}{lcc}
\hline Variables & $\mathrm{N}$ & $\%$ \\
\hline Perform zootechnical control & & 35.0 \\
$\quad$ Yes & 22 & 65.0 \\
No & 40 & 65.0 \\
Aids used for zootechnical control & 26 & 30.0 \\
$\quad$ Cards & 12 & 5.0 \\
Book & 02 & \\
$\quad$ Computer & & 66.0 \\
Receive technical assistance & 41 & 34.0 \\
Yes & 21 & 58.0 \\
No & & 8.0 \\
Type of technical assistance & 31 & 34.0 \\
Public & 10 & \\
Particular & 21 & 70.0 \\
None & & 30.0 \\
Type of reproductive technique & 43 & 0.0 \\
Natural mating in the field & 19 & \\
Controlled natural mating & 00 & \\
Artificial insemination & &
\end{tabular}

$\mathrm{N}=$ number of answers in the questionnaire

$\%=$ percentage of answers in the questionnaire.

Technical assistance can positively influence the way the farm is managed, because the technician will pass on guidance and knowledge to the producer, who will practice everything he has learned, thus guaranteeing the success of the activity. The results indicated that $66 \%$ of the producers received technical assistance. Technical assistance was provided (58\%); however, 34\% of the farmers interviewed did not receive any type of technical assistance. Producers who do not have technical assistance belong to the highest risk group, for being subjected to a lower sanitary criteria and being more likely to disseminate diseases.

A great majority of farms did not adopt the practice of reproductive control, allowing very young females or females with reproductive problems to be available for mating. This creates negative effects such as damage to body development, in the case of very early reproduction, and the maintenance of unproductive animals, in the case of females with reproductive problems. Of the farms surveyed, $70 \%$ of the population did not utilize reproductive control. Only $58 \%$ of the productive farms received technical assistance suggests that this monitoring may be partially or insufficiently done, since basic management issues and reproductive control are not being adequately addressed.

Natural mating is widely used in the northeast because it is the simplest method and their breeding systems favor this practice. The animals are 
raised free, allowing the reproducing males to be introduced to the females. It can also be performed in a directed way, by taking the females to the male for mating, or by leaving the females alone with the male, with mating occurring without any control on the part of the breeder. Early reproductive age is directly related to the reproductive system and technique.

Regarding the sanitary aspect, $78 \%$ of the productive farms carried out vaccinations for clostridia and rabies, as well as periodical vermifuging. Vaccinations occurred according to the vaccination schedule. When asked about the frequency of diseases in the goat and sheep herds, $37 \%$ answered that worm infections occurred more frequently, especially in the rainy season, when the loss of animals increased considerably. For the treatment of diseased animals, $86 \%$ of the farms separated and treated their animals (Table
7). When asked about the season of application, the producers stated that they always carried out vermifuging according to the technical guidelines, which advises one vermifuge to be done in the rainy season (March/April) and another in the dry season (October/November). In the current study however, it is known that for the effective control of parasitic diseases, it is necessary to take into account not only rainfall aspects of the region, but a range of factors, such as the animal species involved, management practices, parasite prevalence, type of pasture, and even the breeding systems employed, since it is known that in the northeast, the semiintensive system favors parasitic dissemination, thus requiring specific care (COSTA et al., 2011). Therefore, the form of parasitic control adopted by breeders of small ruminants in the region may not be sufficient, thereby jeopardizing the productive efficiency of the animals.

Table 7. Qualitative variable analysis of sanitary aspects of goat and sheep rearing in the semi-arid region of Paraíba.

\begin{tabular}{lcc}
\hline Variables & $\mathrm{N}$ & $\%$ \\
\hline Performing vaccination and vermifugation & & 78.0 \\
$\quad$ Periodic & 48 & 22.0 \\
$\quad$ Eventual & 22 & \\
Most frequent diseases & & 33 \\
$\quad$ Caseous lymphadenitis & 20 & 37 \\
Worms & 23 & 12 \\
Foot pad dermatitis & 08 & 11 \\
Contagious ecthyma & 07 & 7.0 \\
No frequent diseases & 04 & \\
Care of sick animals & & 86.0 \\
Separate and treat & 53 & 9.0 \\
Do not treat & 06 & 5.0 \\
Discard & 03 & \\
\hline
\end{tabular}

$\mathrm{N}=$ number of answers in the questionnaire

$\%=$ percentage of answers in the questionnaire.

The results of this study are similar to those observed in other production systems of small ruminants practiced in America. Studies carried out in Argentina (ARIAS; ALONSO, 2002), Mexico (PÉREZ et al., 2010; HERNÁNDEZ et al., 2011; RODRÍGUEZ et al., 2011), Chile (MUJICA et al., 2015), Venezuela (MORANTES et al., 2008) and the Dominican Republic (VALERIO et al., 2009) show that the activity is practiced mostly by small producers with a low level of education (fewer than ten years of study), high average age of the producer (over 45 years), with a tendency to 
a low level of organization in the farms, having the practice as a secondary business with the exception of the Dominican Republic, where it is considered the main business of the producers. The herds are composed of mixed herds of goats, sheep, and cattle, predominantly of extensive or grazing and semiextensive systems, without reproductive control and with few sanitary practices such as vaccination against diseases and treatment against internal and external parasites.

Comparison of the results of this study with those observed in production systems in Africa show both differences and similarities. In Sub-Saharan Africa, communal grazing systems were observed, where goat herds of small farmers living in the villages were raised together (GWASE et al., 2009), which differs from the system observed in Paraíba, where small farmers own the lands where they raise their animals. Studies in South Africa and Kenya show the occurrence of diseases in small ruminants as a limiting factor to production (KOSGEY et al., 2008; SLAYI et al., 2014), which was also observed in the present study. However, in South Africa, incentive programs were implemented towards the commercialization and genetic improvement of herds that favored the productivity of native breeds (ROETS; KIRSTEN, 2005; MOHLATLOLE et al., 2015), a fact which was not observed in this research, where the goat breeds that had some genetic improvement, mainly dairy breeds, originated from exotic breeds such as Saanen and Anglo-Nubian.

In Europe, especially in countries of the Mediterranean region such as Spain, France, Italy, and Greece, differences were observed between production systems practiced in these countries and those in the semi-arid region of Paraíba. The goat and sheep herds of the Mediterranean region are raised in systems ranging from intensive to extensive, with the intention of producing goat and sheep milk (RANCOURT et al., 2006). In the present study, most breeders own herds for meat production; however, in the Cariri region of Paraíba, most of the producers have dairy goats, which has differentiated this region from the other regions studied as a more technological production system, therefore enabling a more profitable operation. Studies conducted in the regions of Spain, where the production of dairy goats is predominant, shows the economic importance of the activity for those regions, mainly regarding the implementation of technology in the farms, which allows greater productivity of the herds (NAHED et al., 2006; CASTEL et al., 2010).

In general, these results indicate the social and economic importance of raising small ruminants, since family labor is employed by most producers, thus establishing families in rural areas, producing animal protein for food, and generating income for the region where it is practiced.

\section{Conclusion}

The results of this study allowed to classify goat and sheep production systems in the semi-arid Paraíba as a family system and one of subsistence, for farmers' own consumption and local trade, with low technology use and herds with up to 100 animals. The farmers' level of education was low, and the investments and technical assistance for the development of the goat and sheep rearing activity in the region were insufficient and/or inadequate. Thus, it is essential to conduct an economic study of the farms to know the actual economic and financial status of the activity and the returns that they can provide from their organization. It is suggested that these aspects need to be taken into account when planning livestock development policies, especially in terms of financing and technical assistance, as well as in the implementation of strategies to control commonly occurring diseases in the region, aimed at combating agents, environmental control, and protection of the susceptible livestock. 


\section{References}

ALENCAR, S. P. Aspectos socioeconômicos e sanitários dos rebanhos caprinos e ovinos no sertão de Pernambuco. Pernambuco. 2008. Tese (Doutorado em Ciência Veterinária) - Universidade Federal Rural de Pernambuco, Recife.

ALENCAR, S. P.; MOTA, R. A.; COELHO, M. C. O. C.; NASCIMENTO, S. A.; ABREU, S. R. O.; CASTRO, R. S. Perfil sanitário dos rebanhos caprinos e ovinos no sertão de Pernambuco. Ciência Animal Brasileira, Goiânia, v. 11, n. 1, p. 131-140, 2010.

ALMEIDA, A. C. S. Caracterização dos produtores e propriedades rurais em três municípios do Estado de Pernambuco. Revista Caatinga, Mossoró, v. 19, n. 4, p. 323-332, 2006.

ALMEIDA, R. F. Palma forrageira na alimentação de ovinos e caprinos no semiárido brasileiro. RevistaVerde de Agroecologia e DesenvolvimentoSustentável, Mossoró, v. 7, n. 4, p. 8-14, 2012.

ALVES, J. J. A. Caatinga do cariri paraibano. Genomos, Belo Horizonte, v. 17, n. 1, p. 19-25, 2009.

ARIAS, M.; ALONSO, A. Estudio sobre sistemas caprinos del norte de la Provincia de Córdoba, Argentina. Archivos de Zootecnia, Córdoba, v. 51, n. 195, p. 341349, 2002.

BANDEIRA, D. A.; CASTRO, R. S.; AZEVEDO, E. O.; MELO, L. S. S.; MELO, C. B. Característica de produção da caprinocultura leiteira na região do cariri na Paraíba. Ciência Veterinária nos Trópicos, Recife, v. 10, n. 1, p. 29-35, 2007.

BRITO, V. A. O espaço agrário da ovinocaprinocultura no Sertão Noroeste de Sergipe no período de 1980 a 2003. 2006. Dissertação (Mestrado em Geografia) - Fundação Universidade Federal de Sergipe, Aracaju.

CASTEL, J. M.; RUIZ, F. A.; MENA, Y.; SÁNCHESRODRÍGUEZ, M. Present situation and future perspectives for goat production systems in Spain. Small Ruminant Research, Amsterdam, v. 89, n. 2, p. 207-210, 2010.

CASTRO, M. B.; CHARDULO, L. A. L.; SZABO, M. P. J. Copper toxicosis in sheep fed dairy cattle ration in São Paulo, Brazil. Arquivo Brasileiro de Medicina Veterinária e Zootecnia, Belo Horizonte, v. 59, n. 1, p. 246-249, 2007.

COSTA, V. M. M.; SIMÕES, S. V. D.; RIET-CORREA, F. Controle das parasitoses gastrintestinais em ovinos e caprinos na região semiárida do Nordeste do Brasil. Pesquisa Veterinária Brasileira, Rio de Janeiro, v. 31, n. 1, p. 65-71, 2011.
DRUMOND, M. A. Recomendações para o uso sustentável da biodiversidade no bioma da Caatinga. In: Biodiversidade da Caatinga: áreas e ações prioritárias para a conservação. Brasília: MMA-UFPE; Brasília, 2004. p. 47-90.

FARIA, G. A.; MORAIS, O. R.; GUIMARAES, P. H. S. Análise da ovinocaprinocultura no Norte e Nordeste de Minas Gerais. Belo Horizonte: SEBRAE, MG, FAEMG, EMATER, 2004. 122 p.

GIRARDI, G.; ROSA, J. V. Atlas geográfico do estudante. São Paulo: FDS S. A., 2011. 160 p.

GONÇALVES, A. L.; LANA, R. P.; VIEIRA, R. A. M. Avaliação de sistemas de produção de caprinos leiteiros na Região Sudeste do Brasil. Revista Brasileira de Zootecnia, Viçosa, MG, v. 37, n. 2, p. 366-376, 2008.

GUIMARÃES FILHO, C. Efeito do pastejo suplementar em capim buffel durante o período seco na taxa anual de parição de vacas criadas na caatinga. Pesquisa Agropecuária Brasileira, Brasília, v. 29, n. 1, p. 139-143, 1994.

GUIMARÃES FILHO, C.; SOARES, J. G. G. Avaliação de um modelo físico de produção de bovinos no semiárido integrando caatinga, capim buffel e leucena. Pesquisa Agropecuária Brasileira, Brasília, v. 34, n. 9, p. 1721-1727, 1999.

GWASE, R. F.; CHIMONYO, M.; DZAMA, K. Communal goat production in Southern Africa: a review. Tropical Animal Health and Production, Amsterdã, v. 41, n. 7, p. 1157-1168, 2009.

HERNÁNDEZ, P. P.; ARRONIZ, J. V.; MOLINA, H. C.; MARTINEZ, B. C.; RIVERA, P. D.; ORTIZ, S. L. Análisis descriptivo de los sistemas de produccíon con ovinos en el Estado de Veracruz, México. Revista Cientifica FCV-LUZ, Maracaibo, v. 21, n. 4, p. 327-334, 2011.

HOLANDA JUNIOR, F. I. F.; CAMPOS, R. T. Análise técnico econômica da pecuária leiteira no município de Quixeramobim - estado do Ceará. Revista Econômica do Nordeste, Fortaleza, v. 34, n. 4, p. 621-646, 2003.

INSTITUTO BRASILEIRO DE GEOGRAFIA E ESTATÍSTICA - IBGE. Produção Pecuária Municipal. Rio de Janeiro: IBGE, 2012. Disponível em: <http:// www.ibge.gov.br/home/estatistica/economia/ppm/2012/ default pdf.shtm>. Acesso em: 23 out. 2014.

Produção Pecuária Municipal. Rio de Janeiro: IBGE, 2014. Disponível em: <http://www.ibge.gov. br/ home/estatistica/economia/ppm/2014/default_xls_perfil. shtm>. Acesso em:14 maio 2016. 
KOSGEY, I. S.; ROWLANDS, G. J.; VAN ARENDONK, J. A. M.; BAKER, R. L. Small ruminant production in smallholder and pastoral/extensive farming systems in Kenya. Small Ruminant Research, Amsterdam, v. 77, n. 1, p. 11-24, 2008.

LIMA, A. M. C. Brucelose ovina: soroprevalência e análise dos fatores de risco nos estados do Rio Grande do Norte, Paraíba e Sergipe. 2015. Dissertação (Mestrado em Zootecnia) - Universidade Estadual Vale do Acaraú, Sobral.

LIMA, R. G. S.; BAIARDI, A. Estratégias de sobrevivência dos pequenos caprinocultores do semiárido baiano. Riode Janeiro: SOBER, 2000. CDROM. Disponível em: <http://www.66.102.1.104/ scholar?hl $=$ pt\&lr $=\& q=$ cache:bEN9qlIJlYJ:gipaf.cnptia. embra.br/itens/publ/sober2000/limargs/Paper593.PDF+ + importancia + cultural + do + caprio $>$. Acesso em: 18 jun. 2014

MOHLATLOLE, R. P.; DZOMBA, E. F.; MUCHADEYI, F. C. Addressing production challenges in goat production systems of South Africa: the genomics approach. Small Ruminant Research, Amsterdam, v. 131, n. 1, p. 43-49, 2015.

MONTE, E. Z.; TEIXEIRA, E. C. Determinantes da adoção da tecnologia de despolpamento na cafeicultura. Revista de Economia e Sociologia Rural, Rio de Janeiro, v. 44, n. 2, p. 201-217, 2006.

MORANTES, M.; RODÓN, Z.; COLMENARES, O.; ÁLVAREZ, L. R.; ZAMBRANO, C. Análisis descriptivo de los sistemas de producción con ovinos en el Municipio San Genaro de Boconoito (Estado Portuguesa, Venezuela). Revista Cientifica FCV-LUZ, Maracaibo, v. 18, n. 5, p. 556-561, 2008.

MUJICA, P. T.; AGUILAR, C.; VERA, R.; RIVAS, J.; GARCÍA, A. Sheep production systems in the semi-arid zone: changes and simulated bio-economic performances in a case study in Central Chile. Livestock Science, Amsterdam, v. 180, n. 1, p. 209-219, 2015.

NAHED, J.; CASTEL, J. M.; MENA, Y.; CARAVACA, F. Appraisal of the sustainability of dairy goat systems in Southern Spain according to their degree of intensification. Livestock Science, Amsterdam, v. 101, n. 1, p. 10-23, 2006.

OLIVEIRA, M. C.; SILVA, C. M. M.; ALBUQUERQUE, S. G.; BERNARDINO, F. A. Comportamento de gramineas forrageiras sob condições de pastejo intensivo por bovinos na região semi-árida do nordeste do Brasil. Petrolina: EMBRAPA-CPATSA, 1988. 15 p. (EMBRAPA-CPATSA. Documentos, 56).
PINHEIRO, R. R.; GOUVEIA, A. M. G.; ALVES, F. S. F.; HADDAD, J. P. A. Aspectos epidemiológicos da caprinocultura cearense. Arquivo Brasileiro de Medicina Veterinária e Zootecnia, Belo Horizonte, v. 52, n. 5, p. 534-543, 2000.

PÉREZ, R. D. G.; GONZÁLES, S. F. G.; MAGAÑA, M. A. M.; LARA, P. E. L. Caracterización técnica y socioeconómica de la producción ovina en el estado de Yucatán, México. Agronomina Mesoamericana, Alajuela, v. 21, n. 1, p. 131-144, 2010.

PUGH, D. G.; BAIRD, A. N. Sheep and goat medicine. $2^{\text {th }}$ ed. Saunders: Maryland Heights, 2012. 621 p.

RANCOURT, M.; FOIS, N.; LAVÍN, M. P.; TCHAKÉRIAN, E.; VALLERAND, F. Mediterranean sheep and goats production: an uncertain future. Small Ruminant Research, Amsterdam, v. 62, n. 3, p. 167-179, 2006.

RIET-CORREA, B.; SIMÕES, S. V. D.; PEREIRA FILHO, J. M.; AZEVEDO, S. S.; MELO, D. B.; BATISTA, J. A.; MIRANDA NETO, E. G.; RIETCORREA, F. Sistemas produtivos de caprinocultura leiteira no semiárido paraibano: caracterização, principais limitantes e avaliação de estratégias de intervenção. Pesquisa Veterinária Brasileira, Rio de Janeiro, v. 33, n. 3, p. 345-352, 2013.

RODRÍGUEZ, J. R. G.; LÓPEZ, S. V.; RAMÍREZ, J. L. Z.; GONZÁLEZ, A. B.; BRIBIESCA, E. R.; RODRÍGUEZ, J. D. G.; ZEPEDA, J. S. H. Evaluación territorial de los sistemas de producción ovina en la región nor-poniente de Tlaxcala. Revista Mexicana de Ciencias Pecuarias, Cidade do México, v. 2, n. 1, p. 5368, 2011.

ROETS, M.; KIRSTEN, J. F. Commercialisantion of goat production in South Africa. Small Ruminant Research, Amsterdam, v. 60, n. 1, p. 187-196, 2005.

SANTOS, V. W. S. Estudo zoosanitário e fatores de risco associados à Artrite-Encefalite Caprina nos Estados do Ceará, Rio Grande do Norte e Sergipe. 2014. Dissertação (Mestrado em Zootecnia) - Universidade Estadual Vale do Acaraú, Sobral.

SERVIÇO DE APOIO AS MICRO E PEQUENAS EMPRESAS - SEBRAE. Ovinocaprinocultura: diagnóstico. João Pessoa: SEBRAE-PB, 2004. Disponível em: <http://www.sebraepb.gov.br>. Acesso em: 12 set. 2013.

SILVA, E. M. N.; SOUZA, B. B.; SILVA, G. A.; AZEVEDO, S. S.; GOMES, T. L. S. Caracterização dos sistemas produtivos de leite de cabra nos cariris paraibano. Revista Caatinga, Mossoró, v. 26, n. 1, p. 6371, 2013. 
SLAYI, M.; MAPHOSA, V.; FAYEMI, O. P.; MAPFUMO, L. Farmers' perceptions of goat kid mortality under communal farming in Eastern Cape, South Africa. Tropical Animal Health and Production, Amsterdã, v. 46, n. 7, p. 1209-1215, 2014.

SOUZA, B. B.; SILVA, E. M. N.; SILVA, G. A.; NOGUEIRA, F. R. B. Leite de cabra: raças utilizadas e sistemas de alimentação utilizados no cariri paraibano. Piracicaba:AgriPoint, 2011. 5 p. Disponível em: <http:// www.farmpoint.com.br>. Acesso em: 27 jul. 2014.
SOUZA, M. E. C. Diagnostico do sistema produtivo dos ovinocaprinocultores do município de Itinga, Médio Vale do Jequitinhonha - MG. Revista Brasileira de Agroecologia, Porto Alegre, v. 4, n. 2, p. 3529-3532, 2009.

STATISTICA Trial Version for Windows (version 9.0). Tulsa: StatSoft Inc., 2009.

VALERIO, D.; GARCÍA, A.; PEREA, J.; ACERO, R.; GÓMEZ, G. Caracterización social y comercial de los sistemas ovinos y caprinos de la Región Noroeste de República Dominicana. Interciência, Caracas, v. 34, n. 9, p. 637-644, 2009. 